\title{
Vulnerability of National Park Service Beaches to Inundation during a Direct Hurricane Landfall: Fire Island National Seashore
}

\author{
Hilary F. Stockdon and David M. Thompson \\ U.S. Geological Survey \\ FISC-St. Petersburg \\ 600 4th Street S.
}

St. Petersburg, FL 33701

\section{Abstract}

Waves and storm surge associated with strong tropical storms are part of the natural process of barrier-island evolution and can cause extensive morphologic changes in coastal parks, leading to reduced visitor accessibility and enjoyment. Even at Fire Island National Seashore, a barrier-island coastal park in New York where extratropical storms (northeasters) dominate storm activity, the beaches are vulnerable to the powerful, sandmoving forces of hurricanes. The vulnerability of park beaches to inundation, and associated extreme coastal change, during a direct hurricane landfall can be assessed by comparing the elevations of storm-induced mean-water levels (storm surge) to the elevations of the crest of the sand dune that defines the beach system. Maps detailing the inundation potential for Category 1-4 hurricanes can be used by park managers to determine the relative vulnerability of various barrier-island parks and to assess which areas of a particular park are more susceptible to inundation and extreme coastal changes.

\section{Introduction}

Along much of the East Coast of the United States, hurricanes have been responsible for some of the most dramatic changes to our coastal environments - from the creation of large overwash deposits to the opening of new inlets. Strong winds associated with these tropical storms bring large waves and storm surge that force significant changes on fragile barrier islands, where the balance between island stability and rising water levels is maintained by dynamic changes in beach morphology. On developed barrier islands, hurricane-induced coastal change makes local infrastructure more vulnerable to failure. In our national coastal parks, where development is strictly managed, hurricanes threaten to destroy infrastructure that keeps the parks operational (e.g., roads, communications, park buildings) as well as to alter dramatically the beaches and dunes that provide visitors with the opportunity to experience the interaction of the land and the sea.

The impact of a hurricane on a beach has been shown to be highly variable over both large and small stretches of coast (Stockdon et al., 2003) One section of beach may be largely unaffected by a storm, while an adjacent area experiences extreme coastal change associated with island overwash or breaching. This spatially variable response to storms is partly due to longshore variability of the pre-storm beach morphology combined with variability in the offshore physical forcing (Stockdon et al., 2007a). The longshore-variable, potential vulnerability of a barrier island to extreme coastal change during a hurricane landfall can be defined using a storm-impact scaling model that compares the relative elevations of barrierisland morphology and storm-induced water levels (Sallenger, 2000).

A complete and comprehensive management plan preparing for a hurricane landfall, as well as plans for post-hurricane recovery, should be based, in part, on an assessment of what areas of the coast are most vulnerable. In order to help several of our coastal National Parks prepare for a possible hurricane landfall, the USGS, at the request of the National Park Service (NPS), has prepared an analysis of the vulnerability of Fire Island National Seashore (NS) beaches to inundation during a direct landfall. The results can be used to assess what areas of the park are most susceptible to extreme coastal change during a hurricane. These findings can also be compared to those from other NPS coastal parks to determine, in a relative sense, which parks are most at risk during strong tropical storms.

Fire Island NS is an east-west trending barrier island located in New York, south of Long Island (Fig. 1). The $50 \mathrm{~km}$ of barrierisland park include beaches, dunes, marshes, and maritime forest. There are 17 private communities within the boundaries of the park, as well as state and local parks. The beaches along Fire Island are most vulnerable to strong northeaster storms that typically batter the beaches in the fall and winter; however the south-facing beaches are also susceptible to the forces of approaching hurricanes that occasionally move into the North Atlantic Ocean.

\section{Methods}

\subsection{Storm-Impact Scaling Model}

A simple storm-impact scale that compares elevations of the most seaward sand dune to elevations of hurricane-induced water levels can be used to define the likely impact regime for an approaching hurricane (Sallenger, 2000). During a storm, the combined effects of 1) the astronomical tide, 2) storm surge (elevated water levels associated with the large winds and low pressures of a hurricane), and 3) wave runup (the super-elevation of the water surface at the shoreline due to 


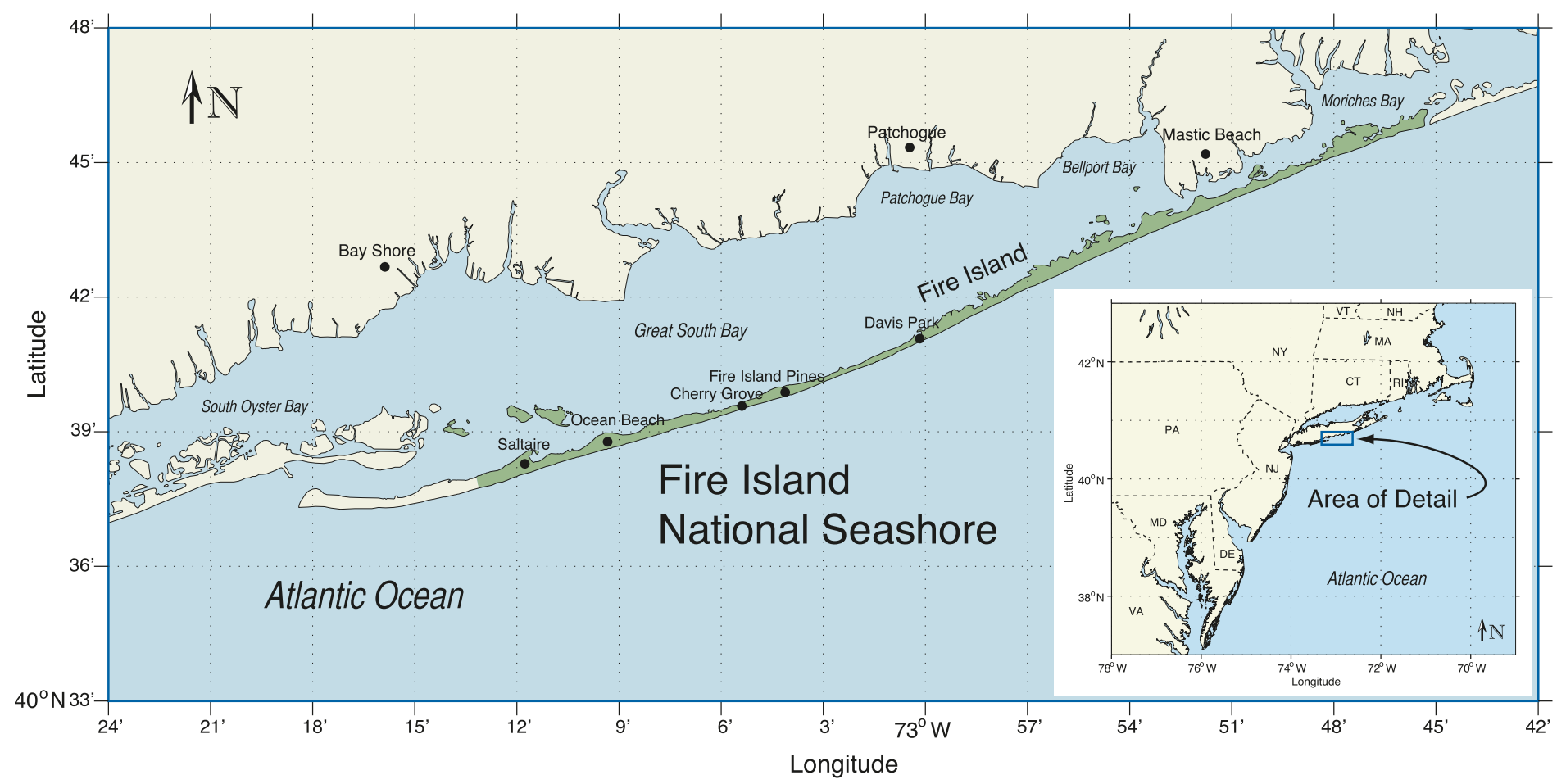

Figure 1. Location map for Fire Island National Seashore.

waves, both the time-varying and time-averaged components) move the erosive forces of the storm higher on the beach face than during typical wave conditions. The total elevation of these three parameters defines the maximum water level $\left(R_{\text {high }}\right)$ attained during a storm, while the storm-induced mean-water level $\left(R_{\text {low }}\right)$ can be defined by only storm surge and wave setup. These forces may reach the elevation of the base $\left(D_{\text {low }}\right)$ and crest $\left(D_{\text {high }}\right)$ of the most seaward sand dunes that define the landward limits of the beach system and represent the first line of defense for a barrier island in an approaching storm. Using these parameters, four storm-impact regimes, or thresholds for coastal change, maybe defined-Swash $\left(R_{\text {high }}<D_{\text {low }}\right)$, collision $\left(R_{\text {high }}>\right.$ $\left.D_{\text {low }}\right)$, overwash $\left(R_{\text {high }}>D_{\text {high }}\right)$, and inundation $\left(R_{\text {low }}>D_{\text {high }}\right)$ - to provide a framework for examining the general types and relative magnitudes of coastal change that are likely to occur during hurricanes (Sallenger, 2000; Stockdon et al., 2007a).

Here we focus on the most extreme of the four impact regimes, inundation, which occurs when the storm-induced meanwater level $\left(R_{\text {low }}\right)$ exceeds the elevation of the crest of the most seaward sand dune $\left(D_{\text {high }}\right)$. Within this regime, the beach system (foredune ridge and beach) is completely submerged, and net landward transport of sediment is likely to occur (Sallenger, 2000). Typically, larger magnitudes of shoreline retreat and beach erosion will occur when the beach is inundated due to the transport of sand in both the offshore and onshore directions (Stockdon et al., 2007a).

The predictive accuracy of the scaling model was tested by hindcasting the likely impact of Hurricanes Bonnie and Floyd (Stockdon et al., 2007a) and of Hurricane Ivan (Stockdon et al., 2007b). For Hurricane Ivan, the overall hindcast accuracy of the model in predicting one of the four regime types was $68 \%$. The sensitivity of the model within the inundation regime was $51 \%$ (Stockdon et al., 2007b). Underprediction errors were likely due to profile evolution of the low-lying barriers during the landfall of this Category 4 storm. In order to use this model in a predictive mode to examine the potential for inundation during a future hurricane landfall, accurate estimates of both the dune parameters and the expected hurricane-induced mean-water level are needed.

\subsection{Dune Elevation}

The morphology of the beach and dunes at Fire Island NS was mapped based on an airborne lidar topographic survey conducted on April 29, 2007, by the USGS and NASA using NASA's Experimental Advanced Airborne Research Lidar (EAARL). GPS-based lidar surveys provide an efficient method for collecting high-resolution data of subaerial topography with sufficient accuracy (root-mean-square vertical accuracy $=15 \mathrm{~cm}$ ) to resolve the spatial details of sand-dune elevation and position (Sallenger et al., 2003). These data were collected approximately two weeks after a large northeaster storm delivered large waves and strong winds to the area. Because changes to dunes during storms are generally more long-lasting than changes on the beach face, this post-storm survey was used to measure the most current morphology of the dunes and to define the potential inundation of Fire Island.

The elevation of the foredune crest (or, in the absence of a dune, the beach berm) was extracted every $20 \mathrm{~m}$ along the coast of Fire Island NS from cross-shore profiles of lidar topography (Fig. 2). An automatic algorithm was used to select the peak of the most seaward dune within a prescribed beach width (here, $150 \mathrm{~m}$ ). The results were then manually checked to ensure the extraction of a consistent feature defining the landward extent of the beach system (Fig. 3). 


\subsection{Storm Surge}

In this analysis, $R_{\text {low }}$ is represented only by the storm surge. Wave setup was not considered because predictions of wave conditions (height and period) for a generic hurricane of each category are not currently available. The predicted elevations of storm surge for Saffir-Simpson Category 1-4 hurricanes were extracted from the NOAA SLOSH (Sea, Lake, and Overland Surges from Hurricanes) model, a real-time forecast model for hurricane-induced water levels for the Gulf and Atlantic Coasts. (Note: The NOAA SLOSH model does not simulate the storm surge associated with Category 5 landfall in the New York basin or any neighboring basins.) The numerical model is based on linearized, depth-integrated equations of motion and continuity (Jarvinen and Lawrence, 1985). Storm surge is modeled by simulating the conditions of each category storm approaching the coast from different angles and at varying speeds. Changes in maximum surge elevations are forced by time-varying windstress and pressure-gradient forces that depend on hurricane location, minimum pressure, and size measured from the eyewall out to the location of maximum winds (Jarvinen and Lawrence, 1985). The maximum surge within each grid cell is defined as the Maximum of the Maximum Envelope of Water (MOMs) and represents the worst-case, localized surge that will occur for landfall in a given location, not what would occur along the entire coast for a single storm. The results are location specific, accounting for local water depths, proximity to bays and rivers, etc., and are accurate to $\pm 20 \%$ of the calculated value (NOAA, 2007). Errors in the SLOSH model can arise from differences between the parametric wind models, which force SLOSH, and the actual hurricane wind field (Houston et al., 1999), as well as discrepancies between the coarse model grid and the real topography and bathymetry over which the storm will travel.

For Fire Island NS, the maximum surge at the shoreline was extracted from the MOMs results for the New York model grid (Fig. 4, left). Maximum, open-coast surge values were

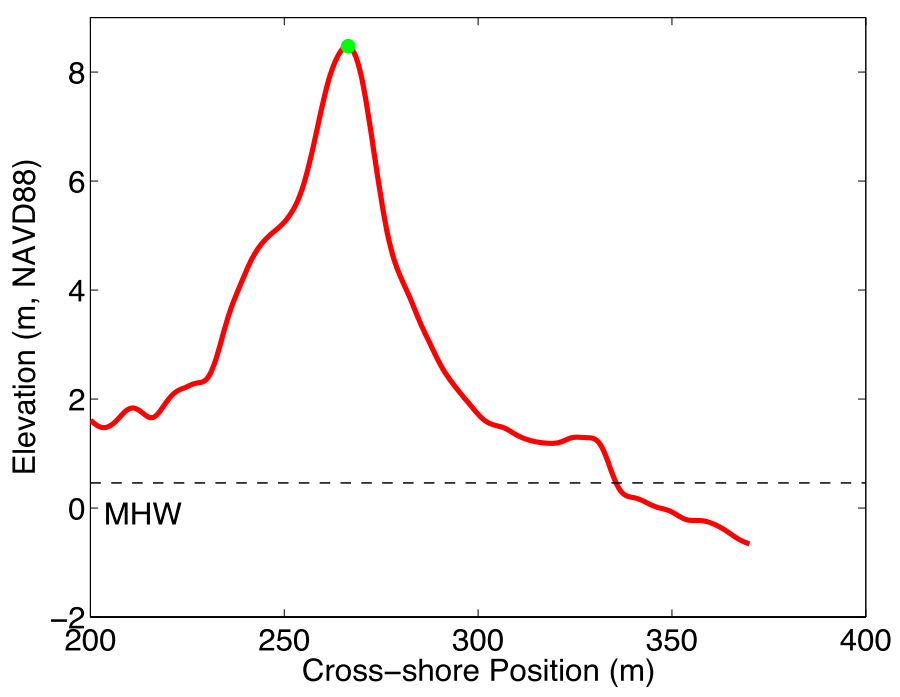

Figure 2. Cross-shore profile of lidar data from Fire Island NS showing the location of the most seaward sand dune. The ocean is located to the right. extracted at the location of the April 2007 lidar-derived, meanhigh-water (MHW, $0.46 \mathrm{~m}$ NAVD88) shoreline position (Fig. 4, right). The New York SLOSH-model grid has an approximate cell size of $3.4 \mathrm{~km}$ to $5.3 \mathrm{~km}$ along the shoreline of Fire Island NS. In locations where grid resolution resulted in anomalously low values because the barrier island was not fully resolved, the most nearshore grid cell representing conditions seaward of the barrier island was chosen.

\section{Inundation Vulnerability}

The potential inundation, $I$, of the beach system was defined every $20 \mathrm{~m}$ along Fire Island NS by calculating the difference between the elevations of SLOSH-modeled storm surge $\left(R_{\text {low }}\right)$ for each hurricane category and of lidar-measured dune crests $\left(D_{\text {high }}\right)$ (Fig. 5). Negative values (blues) indicate that water levels are predicted to be lower than the dune crest and that a particular section of beach is not likely to be inundated during the direct landfall of a hurricane. Positive values (reds) signify areas where the beach is more likely to be inundated by storm surge. These estimates assume landfall at mean astronomical tide and do not include the effects of wave setup, which, during strong storms (Category 3 and above), may increase the storminduced mean-water level by more than $30 \%$ above that due to storm surge alone. This would increase the vulnerability to inundation. Additionally, the maps represent the vulnerability of the beach system as it was at the time of the April 2007 lidar survey. Major changes to beach morphology, such as those caused by large storms and hurricanes, may change the future vulnerability of this stretch of coast.

For the direct landfall of a Category 1 storm, less than $1 \%$ of the Fire Island NS coast is vulnerable to inundation, compared to over $72 \%$ during a Category 4 storm. The vulnerability for a single category storm is highly variable along the length of the park due to spatial variations in the height of the frontal dune. The mean elevation of $D_{\text {high }}$ is $5.44 \mathrm{~m}$ NAVD88 with substantial longshore variability; standard deviation, $\sigma,=1.32 \mathrm{~m}$ (Fig. 6). The surge is less spatially variable: alongshore averaged surge for a Category 1 hurricane was $2.22 \mathrm{~m}$ NAVD88 $(\sigma=0.09 \mathrm{~m})$, and the average surge for a Category 4 storm was $6.02 \mathrm{~m}(\sigma=$ $0.34 \mathrm{~m}$ ) (Fig. 6). While the variability of $I$ and $D_{\text {high }}$ dominate the signal along Fire Island NS, the lower dunes and berms in the northern $2.5 \mathrm{~km}$ of Otis Pike Wilderness Area (Fig. 6) make this area more susceptible to inundation: generally, $R_{\text {low }}>D_{\text {high }}$ for this area for Category 2 and higher storms.

\section{Recent Shoreline Change}

A USGS analysis of historic (150-yr) rates of shoreline change for the northeast United States, including Fire Island NS, is ongoing and will be published within the next year. Recent magnitudes of shoreline change along Fire Island have been calculated between a lidar survey collected in October 2005, following a northeaster storm, and the modern shoreline position as defined using the April 2007 lidar survey that was the basis of the inundation analysis. From each lidar survey, datum-based $(\mathrm{MHW}=0.46 \mathrm{~m})$ shoreline positions were 


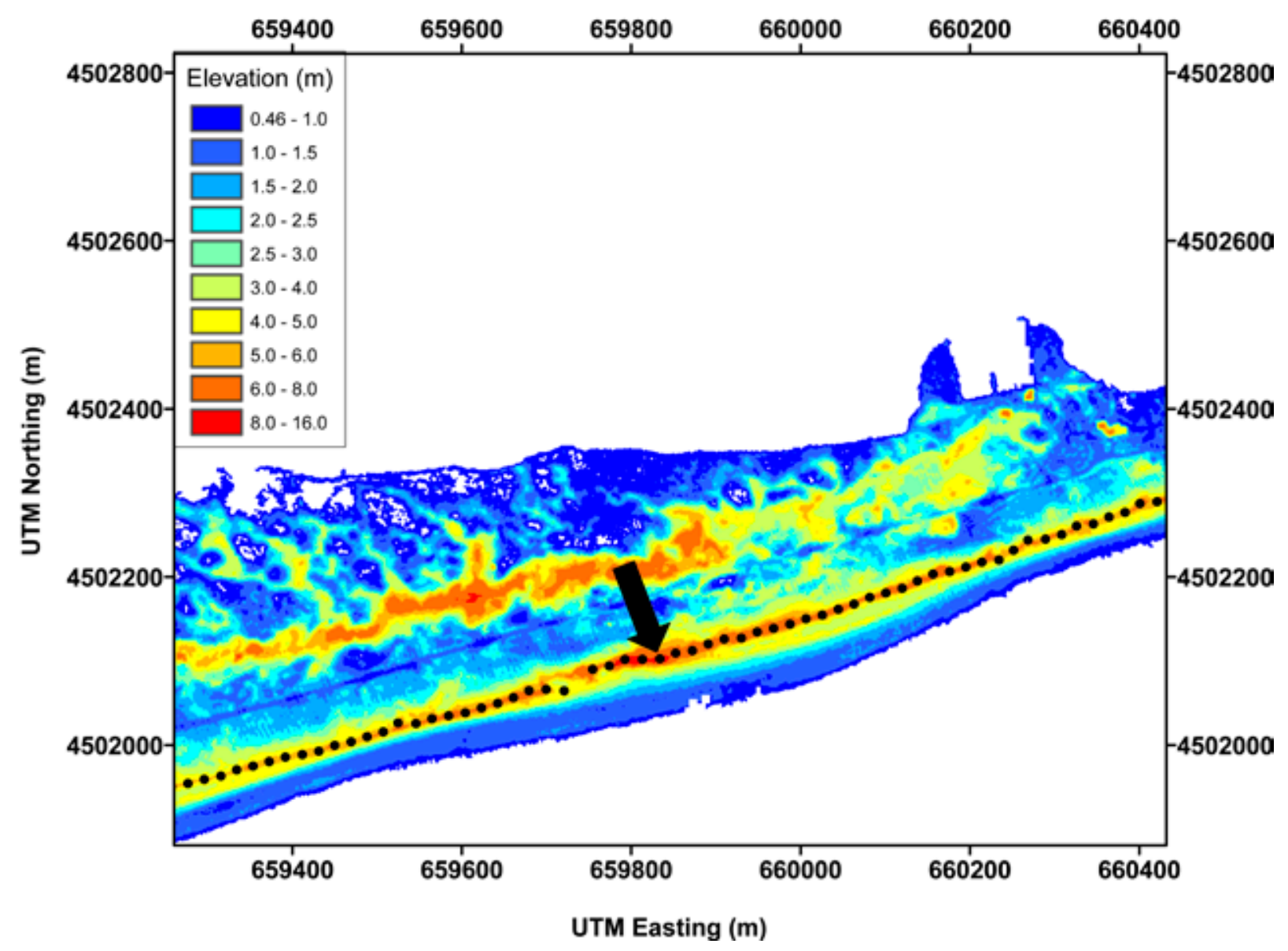

Figure 3. The extracted crest of the dune line for approximately $1.2 \mathrm{~km}$ of the Fire Island NS coast, superimposed on the lidar topography. The arrow refers to the location of the profile shown in Figure 2.
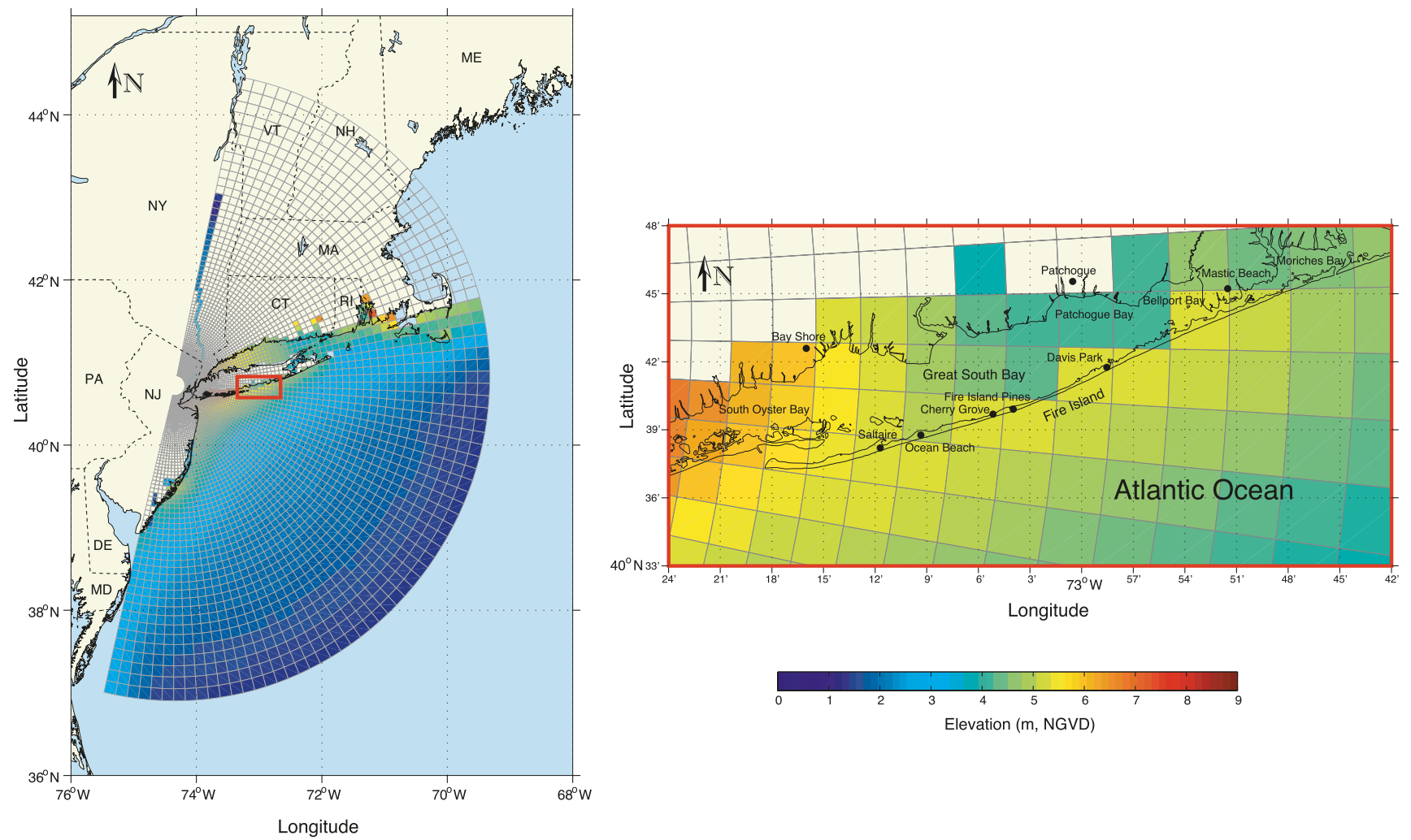

Figure 4. SLOSH-model results for a Category 3 hurricane for the New York model grid (left) shows the variability of modeled surge values along the coast. Maximum, open-coast surge levels were extracted from the SLOSH grid along the Atlantic shoreline of Fire Island NS (right). 


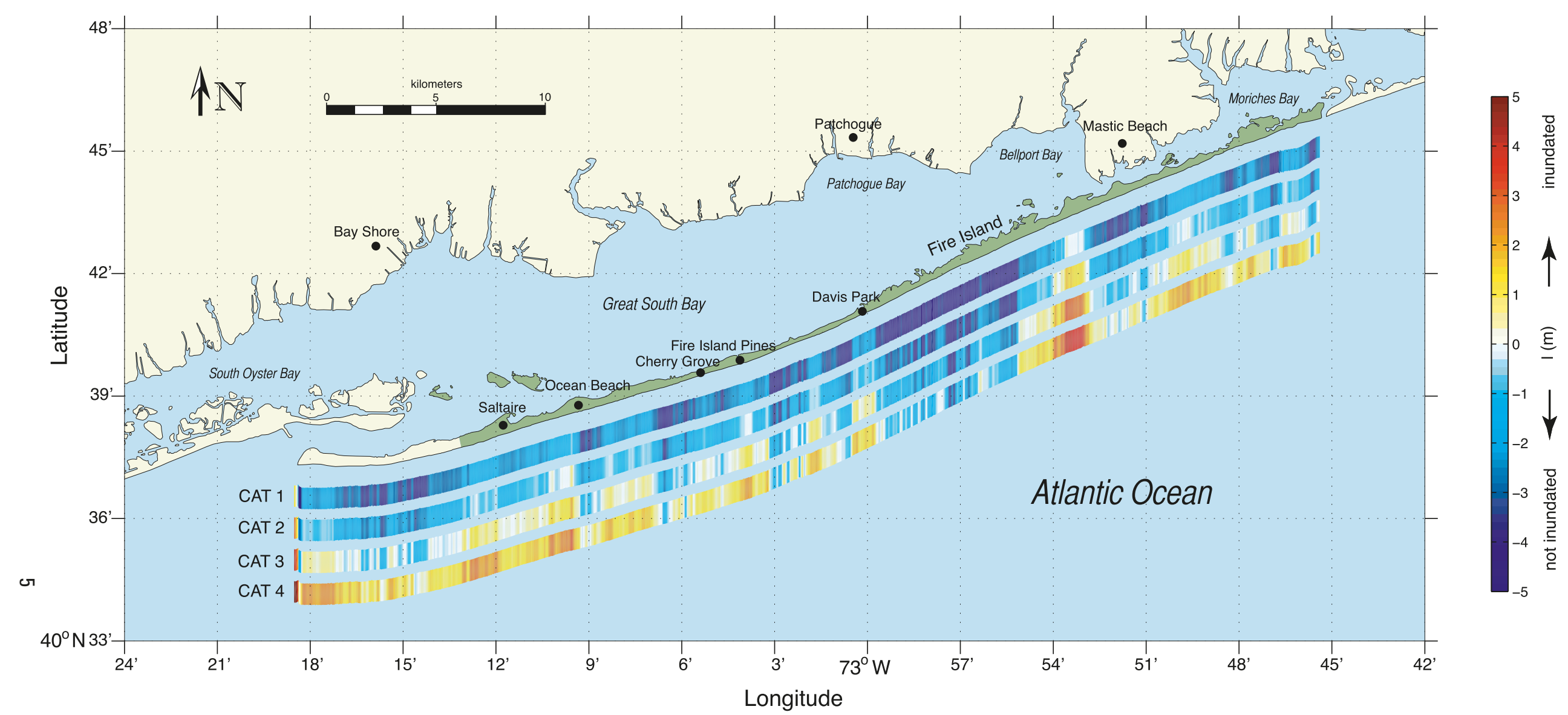

Figure 5. The potential inundation, $I$, of the beach system at Fire Island NS for Category 1-4 hurricanes is defined as the difference between $R_{\text {low }}$ and $D_{\text {high }}$. A 200-m smoothing window was applied to the data before plotting. Positive values indicate that modeled storm surge exceeds the elevation of the dune crest, suggesting that the beach system is more vulnerable to inundation and the associated extreme coastal changes. A larger version of this map can be downloaded from http://coastal.er.usgs.gov/nps-beaches/. 


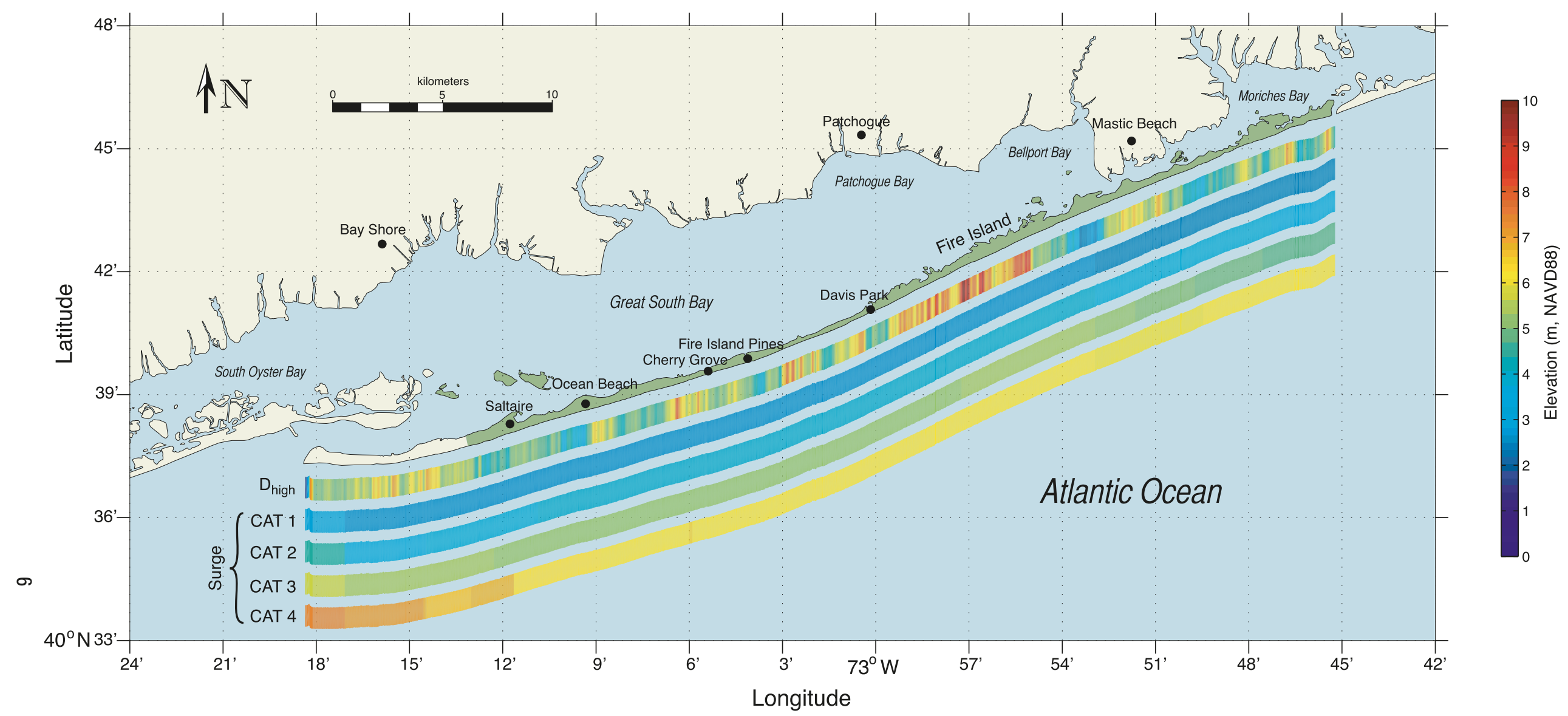

Figure 6. Dune elevations $\left(D_{\text {high }}\right)$ for Fire Island NS were measured from a lidar topographic survey conducted on April 29, 2007. The surge values $\left(R_{\text {low }}\right)$ for Category 1-4 hurricanes were extracted from the NOAA SLOSH model and represent the open-coast 'maximum of the maximum.' A larger version of this map can be downloaded from

http://coastal.er.usgs.gov/nps-beaches/. 
extracted every $20 \mathrm{~m}$ along the coast using techniques described in Stockdon et al. (2002).

Because two post-storm surveys were compared, the results are more representative of the background shoreline-change signal and are not intended to quantify storm-induced change. Horizontal movement of the shoreline, calculated as the difference in position between 2007 and 2005, showed significant longshore variability along the coast of Fire Island NS. The mean shoreline change was $8.76 \mathrm{~m}$; however, the standard deviation was $21.81 \mathrm{~m}$ (Fig. 7). A detailed explanation of the patterns of shoreline change observed will require an indepth study of the wave conditions for each of the northeaster storms, as well as information on the typical wave conditions at the site. Additionally, in order to understand the storm recovery processes of beaches and dunes on a heavily managed coastline, the timing and quantities of human-induced sand movement (e.g., replenishments, dune rebuilding, beach scraping, etc.) must be considered. Only then, can the natural processes of island response to and recovery from a storm be separated from human-induced changes. Details on the magnitudes of shoreline change and the associated error bars for the length of the park can be found at http://coastal.er.usgs.gov/nps-beaches/.

\section{Discussion}

The vulnerability maps detail the worst-case storm-surge scenario for each location along the coast. For open-coast barrier islands, maximum surge typically occurs to the right of landfall under the eyewall and decreases with distance away from the center of the storm. Consequently, the worst case for any given storm is localized and will not occur along the entire coast of Fire Island NS. The map shows areas that are most likely to be inundated by storm surge should the hurricane make landfall immediately to the west of that particular location.

If the beach system is inundated, the dune will be overtopped by storm surge. Strong waves and currents may transport large amounts of sand landward across the island. These types of changes have been shown to be more long-lasting because sand removed from the beach face does not typically return in the years following storm landfall (Stockdon et al., 2007a). In locations where the width of the beach system approaches the width of the island, such as the central portion of the island, the currents associated with inundation may cross the island and create new or expose relict inlets.

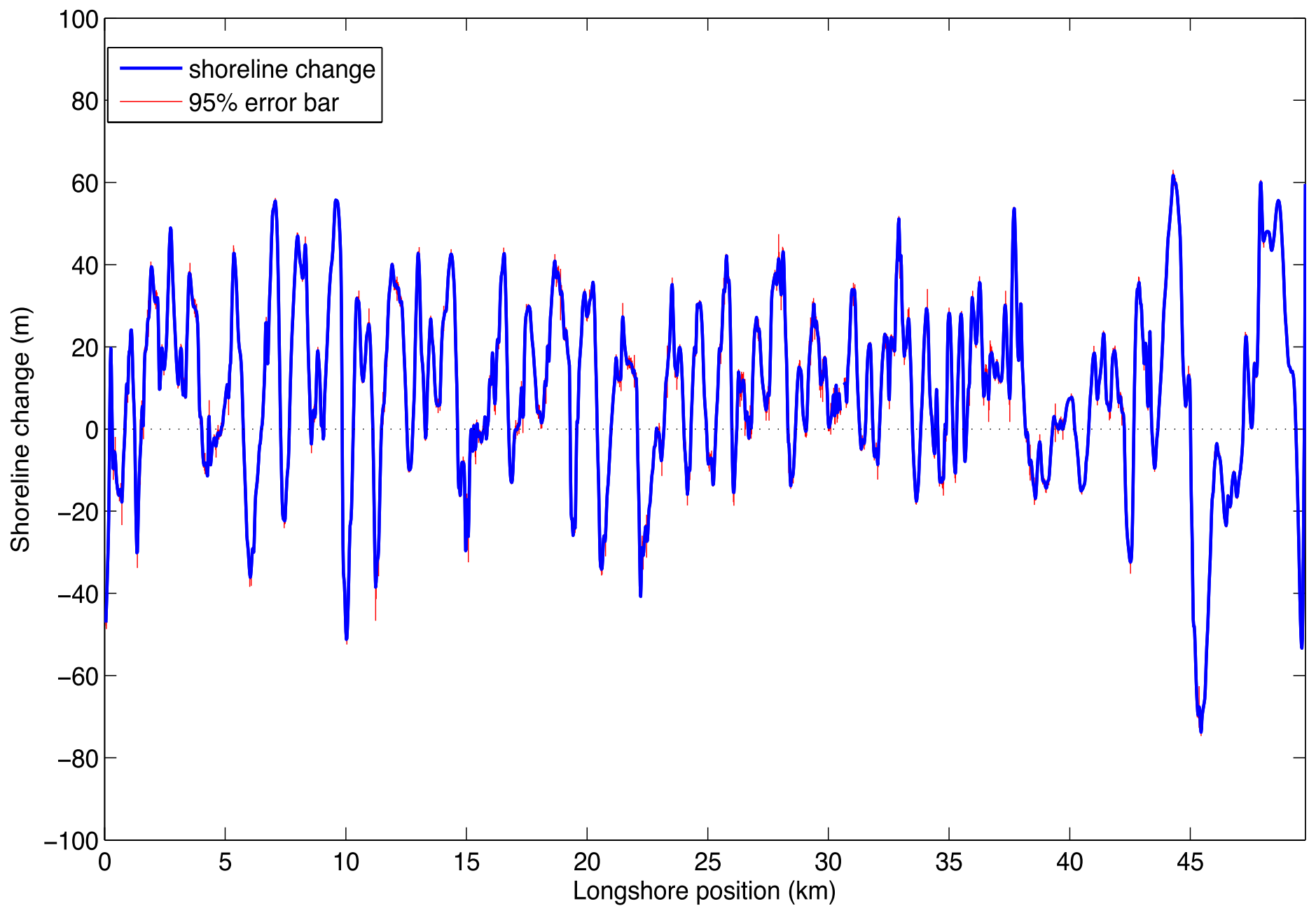

Figure 7. Shoreline change for Fire Island NS as calculated between two post-northeaster lidar surveys conducted in 0 ctober 2005 and April 2007. Data were smoothed with a $100-\mathrm{m}$ window. Negative values indicate erosion. Mean shoreline change over the length of the island is $8.76 \mathrm{~m}$ of accretion. 


\section{Acknowledgments}

We thank Rebecca Beavers and Mark Borrelli (NPS) for their assistance in development of this project. Cheryl Hapke (USGS) provided early reviews of the map products. The lidar data were collected by Wayne Wright (NASA) and his EAARL team. We also thank Betsy Boynton, Kara Doran, Kristy Guy, Peter Howd, Abby Sallenger, Jolene Shirley, Katherine Serafin, and Charlene Sullivan for their contributions to this study. This work was funded by National Park Service, Natural Resource Program Center.

\section{References}

Houston, S.H., Shaffer, W.A., Powell, M.D., and Chen, J., 1999, Comparisons of HRD and SLOSH surface wind fields in hurricanes: Implications for storm surge modeling: Weather and Forecasting, v. 14, p. 671-686.

Jarvinen, B.R., and Lawrence, M.B., 1985, An evaluation of the SLOSH storm surge model: Bulletin of the American Meteorological Society, v. 66, p. 1408-1411.

NOAA, National Hurricane Center, 2007, Hurricane Preparedness: SLOSH model: http://www.nhc.noaa.gov/HAW2/ english/surge/slosh.shtml, last accessed August 24, 2007.

Sallenger, A.H., 2000, Storm impact scale for barrier islands: Journal of Coastal Research, v. 16, p. 890-895.

Sallenger, A.H., Krabill, W., Swift, R., Brock, J., List, J., Hansen, M., Holman, R.A., Manizade, S., Sontag, J., Meredith, A., Morgan, K., and Stockdon, H., 2003, Evaluation of airborne scanning lidar for coastal change applications: Journal of Coastal Research, v. 19, p. 125-133.

Stockdon, H.F., Sallenger, A.H., Holman, R.A., and Howd, P.A., 2007a, A simple model for the spatially-variable coastal response to hurricanes: Marine Geology, v. 238, p. 1-20.

Stockdon, H.F., Sallenger, A.H., Howd, P.A., and Holman, R.A., 2003, Longshore variability of the coastal response to Hurricanes Bonnie and Floyd: Proceedings, International Conference on Coastal Sediments 2003, World Scientific Publishing Corp. and East Meets West Productions, Clearwater Beach, FL.

Stockdon, H.F., Sallenger, A.H., List, J.H., and Holman, R.A., 2002, Estimation of shoreline position and change from airborne scanning lidar data: Journal of Coastal Research, v. 18 , p. 502-513.

Stockdon, H.F., Thompson, D.M., and Sallenger, A.H., 2007b, Hindcasting potential hurricane impacts on rapidly changing barrier islands: Proceedings, 6th International Conference on Coastal Sediments, New Orleans, p. 976-985.

\section{For more information:}

For the USGS:

Hilary F. Stockdon

U.S. Geological Survey

Florida Integrated Science Center-St. Petersburg $6004^{\text {th }}$ Street S.

St. Petersburg, FL 33701

Tel: (727) 803-8747

Email: hstockdon@usgs.gov

For the NPS-GRD:

Mark Borrelli

National Park Service

Natural Resource Program Center

Geologic Resources Division (GRD)

P.O. Box 25287

Denver, CO 80225-0287

Tel: (303) 969-2171 